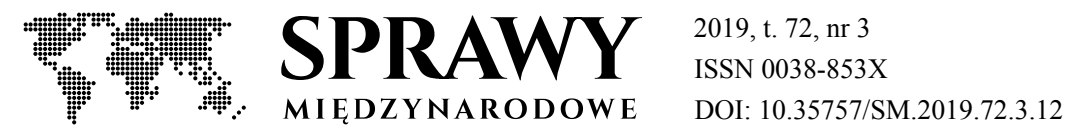

AZJA: KULTURA - EDUKACJA - SPOLECZEŃSTWO

LUKASZ ZAMĘCKI

Uniwersytet Warszawski

ORCID: 0000-0002-2135-6415

\title{
Hongkong AD 2019. Przyczyny i kierunki rozwoju protestów w Specjalnym Regionie Administracyjnym ChRL
}

\author{
Hong Kong AD 2019. Causes and evolution of protests \\ in the Special Administrative Region of the PRC
}

Civil disobedience flooded Hong Kong in 2019. However, protests have changed its character since the last massive demonstrations in 2014. This article outlines direct and contextual reasons for the outbreak of protests in Hong Kong in 2019 from the perspective of Bert Klandermans's model. The aim of the research is also to indicate the directions of protests in this Special Administrative Region of the People's Republic of China. The findings presented are the result of the author's field work carried out since 2012. It should be emphasised that the protests in Hong Kong are the result of the progressive mainlandisation of the region, and in the deeper layer - of the socio-economic problems of citizens. The protests in 2019 brought a change in the tactics of manifesting civil disobedience.

Keywords: Hong Kong, protests, anti-extradition law, China, PRC, mainlandization, HKSAR Słowa kluczowe: Hongkong, protesty, rewolucja parasolkowa, Chiny, ChRL, sinizacja polityczna, Specjalny Region Administracyjny Hongkong 


\section{Wstęp}

Na co dzień nieprzyciągający uwagi Polaków Hongkong pojawił się w $2019 \mathrm{r}$. w centrum dyskusji nad zagadnieniami międzynarodowymi także w kraju nad Wisłą ${ }^{1}$. Polska nie była oczywiście w ostatnich miesiącach odosobniona w swoim zainteresowaniu tym specjalnym regionem administracyjnym Chińskiej Republiki Ludowej, ale fakt, że niewielki, bo liczący $1104 \mathrm{~km}^{2}$ obszar położony w Azji Wschodniej przykuwa uwagę środkowoeuropejskiej opinii publicznej, musi zostać dostrzeżony. Powstaje również pytanie o przyczyny tego zainteresowania.

Pojawienie się kwestii Hongkongu w debacie medialnej jest wynikiem protestów, przeważnie młodych ludzi, które trwają od marca 2019 r. (i nie zakończyły się do czasu powstania tego tekstu, tj. do września 2019 r.)². Celem artykułu jest wskazanie głównych bezpośrednich i kontekstowych przyczyn tych wystąpień oraz kierunku ich rozwoju. Narzędziem analizy będzie model zbudowany na bazie prac Berta Klandermansa dotyczących przyczyn wybuchów kolektywnych działań i uczestniczenia w nich ludzi. Klandermans zaliczany jest obecnie do czołowych badaczy protestów społecznych. Jego kilkudziesięcioletnia kariera zaowocowała szeregiem prac publikowanych w renomowanych czasopismach (indeks $\mathrm{H}$ tego badacza w bazie Scopus to 22), a poczynione przez niego ustalenia weryfikowali empirycznie inni psycholodzy społeczni ${ }^{3}$. Model Klandermansa jest kompleksowy - uwzględnia zarówno kategorie teorii mobilizacji zasobów, jak i psychospołeczne (teorię oczekiwań i teorię działania zbiorowego). Analizując przyczyny udziału

1 Na przykład w „Gazecie Wyborczej” ukazały się w 2019 r. 33 artykuły odnoszące się do Hongkongu, podczas gdy w poprzednim można było naliczyć jedynie 3 wspomnienia, a w 2017 - 10. Por. wyniki wyszukiwania hasła Hongkong w internetowym archiwum „Gazety Wyborczej”: „Archiwum Gazety Wyborczej” [online, dostęp: 3 I 2020], dostępne w internecie: <http://www.archiwum.wyborcza.pl/Archiwum/0,107050.html $>$. Podobnie liczba wyszukiwania w Polsce hasła Hongkong w najpopularniejszej wyszukiwarce Google była w 2019 r. trzykrotnie wyższa niż w latach poprzednich. Zob. Hongkong, „Google Trends” [online, dostęp: 3 I 2020], dostępny w internecie: $<$ https://trends. google.pl/trends/explore?date $=2017-01-01 \% 202020-03-01 \&$ geo=PL\&q=Hongkong $>$.

2 F.L.F. Lee, G. Tang, S. Yuen, E. W. Cheng, Onsite survey findings in Hong Kong's anti-extradition bill protests. Research report, Centre for Communication and Public Opinion Survey, The Chinese University of Hong Kong, August 2019.

3 J. von. Stekelenburg, B. Klandermans, The social psychology of protest, „Current Sociology" 2013, vol. 61, issue 5-6, s. 886-905; M. van Zomeren, T. Postmes, R. Spears, Toward an integrative social identity model of collective action: A quantitative research synthesis of three socio-psychological perspectives, „Psychological Bulletin” 2008, vol. 134, issue 4, s. 504-535. 
w protestach, badacz ten bierze pod uwagę rolę tożsamości, poczucia doznanej krzywdy i osadzenia społecznego. Choć jego dociekania koncentrują się wokół zaangażowania jednostek w działania zbiorowe, to ustalenia, których dokonał, mogą się przyczynić do zaproponowania modelu badań na poziomie mezosystemowym.

Prezentowane $\mathrm{w}$ niniejszej pracy wnioski są efektem prowadzonych od 2012 r. wieloletnich badań terenowych nad przemianami społeczno-politycznymi w Hongkongu, w tym nad postawami tamtejszej młodzieży. W trakcie kilku wizyt badawczych autor przeprowadził m.in. wywiady z lokalnymi politykami, dziennikarzami i naukowcami. Zrealizowana została także praca w grupach fokusowych ze studentami hongkońskich uniwersytetów ${ }^{4}$.

Zrozumienie obecnych protestów wymaga naszkicowania choć krótkiego tła historycznego politycznych i społecznych przemian, które dokonały się w regionie przez ostatnie kilka dekad. W dalszej części artykułu przedstawione zostaną aktualna sytuacja polityczna i społeczno-ekonomiczna Hongkongu, a następnie zarys kierunków zmian form protestów.

\section{Krótka historia polityczna współczesnego Hongkongu}

Podczas dziewiętnastowiecznej ekspansji w Azji Europejczycy zainteresowali się Hongkongiem jako potencjalnym portem i bazą do handlu z cesarskimi Chinami, prezentował bowiem względnie korzystną lokalizację w głębokiej naturalnej zatoce. Okres zachodniego imperializmu w Chinach wyznaczają lata 1842-1898. W wyniku przegranych przez cesarza konfliktów zbrojnych Brytyjczycy narzucili Państwu Środka trzy traktaty, na mocy których najpierw przejęli wyspę Hongkong, a z czasem kolejne części regionu ${ }^{5}$. Od tamtego czasu na mocy decyzji władz brytyjskich region Hongkongu miał status kolonii Zjednoczonego Królestwa.

W traktacie nankińskim z 1842 r. wskazano, że na wyspie Hongkong obowiązywać mają prawa, jakie monarchini uzna za stosowne, a administracja brytyjska miała być tam sprawowana za pośrednictwem wybieranego w Londynie gubernatora. Drugi traktat, czyli będąca rezultatem drugiej wojny opiumowej konwencja pekińska z 1860 r., doprowadził do przejęcia południowej

$4 \quad$ Więcej o metodologii badań zob. Ł. Zamęcki, Rewolucja parasolkowa w Hongkongu. Przyczyny, przebieg, nastęstwa, Wydawnictwa Uniwersytetu Warszawskiego, Warszawa 2018.

5 Region Hongkongu obejmuje wyspę o tej samej nazwie, część półwyspu Koulun i ponad dwieście wysp położonych u ujścia Rzeki Perłowej do Morza Południowochińskiego. 
części półwyspu Koulun. Trzeci natomiast - tj. druga konwencja pekińska z 1898 r., domykająca proces przejmowania władzy nad Hongkongiem przez Brytyjczyków - przyznał Wielkiej Brytanii w formie dzierżawy tzw. Nowe Terytoria, czyli region położony na północ od dotychczasowych zdobyczy. Specyfiką tego ostatniego była 99-letnia dzierżawa ziem chińskich, a nie nabycie ich na wyłączność. Istotny jest przy tym fakt, że Nowe Terytoria stanowiły 92 proc. obszaru całego regionu brytyjskiego Hongkongu.

W okresie kolonialnej administracji Hongkong osiągnął status jednego z najbogatszych regionów świata (pod względem PKB per capita, mierzonego zasobami rezerw złota i walut oraz wysokością eksportu i inwestycji zagranicznych) oraz centrum globalnego handlu i finansów. Zbliżający się termin zakończenia 99-letniej dzierżawy Nowych Terytoriów doprowadził jednak do dyskusji nad przyszłością brytyjskiej obecności w regionie.

Od lat siedemdziesiątych XX w. Brytyjczycy zaczęli bardziej zdecydowanie badać możliwości dalszego administrowania Hongkongiem. Nieustępliwa postawa nieformalnego wówczas przywódcy ChRL Deng Xiaopinga zaprezentowana w marcu 1979 r. podczas wizyty gubernatora Hongkongu Murraya MacLehose'a w Pekinie zamknęła jednak dyskusję na ten temat i rozpoczęła trudny proces negocjacji chińsko-brytyjskich.

Nie wchodząc w szczegóły, należy zaznaczyć, że toczone w latach 1982-1984 formalne pertraktacje w sprawie przyszłości regionu rozpoczęły się od spotkania premier Margaret Thatcher z Deng Xiaopingiem. Na pierwszym, mniej produktywnym etapie, trwającym od lipca 1982 do listopada 1983 r., nie poczyniono większych postępów. Dopiero złagodzenie stanowiska brytyjskiego w drugim okresie negocjacji (grudzień 1983 - wrzesień 1984 r.) umożliwiło osiągnięcie kompromisu ${ }^{6}$ i podpisanie wspólnej deklaracji (Joint declaration of the Government of the United Kingdom of Great Britain and Northern Ireland and the Government of the People's Republic of China on the question of Hong Kong).

Strony ustaliły, że cały region Hongkongu zostanie przekazany ChRL jako specjalny region administracyjny, ale z zachowaniem dotychczasowych swobód, polityk i praw przez okres pięćdziesięciu lat. Rozwiązanie to nazwano zasadą „Jedno państwo, dwa systemy”. Hongkong miał zachować system kapitalistyczny, wymienialną walutę i władze wybierane spośród Hongkończyków. Przyznano mu prawo obecności w organizacjach

6 Y. Ghai, Hong Kong's new constitutional order. The resumption of Chinese sovereignty and the basic law, Hong Kong University Press, Hong Kong 1999, Kindle e-book, lok. 1000. 
międzynarodowych i wydawania własnych dokumentów podróży. Władze centralne ChRL uzyskały jedynie uprawnienia w zakresie obronności i spraw zagranicznych.

We wspólnej deklaracji chińsko-brytyjskiej rozwiązanie to uzyskało tzw. formułę dwunastu zasad:

- Specjalny Region Administracyjny Hongkong (HKSAR) posiadać będzie wysoki stopień autonomii, z wyjątkiem spraw polityki zagranicznej i obronnej, które pozostaną w kompetencji rządu ChRL;

- HKSAR posiadać będzie władzę wykonawczą, ustawodawczą i niezależną władzę sądowniczą, włącznie z prawem do końcowych orzeczeń. Prawo funkcjonujące w Hongkongu pozostanie niezmienione;

- Rząd HKSAR składać się będzie z mieszkańców Hongkongu. Szef egzekutywy będzie powoływany przez rząd centralny ChRL na podstawie wyników wyboru lub konsultacji dokonywanych w Hongkongu. Wyżsi urzędnicy będą nominowani przez szefa egzekutywy;

- System społeczny i gospodarczy Hongkongu pozostanie bez zmian, podobnie jak styl życia. W HKSAR zostaną ustawowo zapewnione prawa i swobody, w tym osobiste, wypowiedzi, prasy, zgromadzeń, stowarzyszeń, podróżowania, przemieszczania się, korespondencji, strajku, wyboru zawodu, badań naukowych i religii. Własność prywatna, własność przedsiębiorstw, uzasadnione prawo spadkowe $\mathrm{i}$ inwestycje zagraniczne będą chronione przez prawo;

- HKSAR zachowa status wolnego portu i odrębnego obszaru celnego;

- HKSAR zachowa status międzynarodowego centrum finansowego, a jego rynki walut, złota, papierów wartościowych i kontraktów terminowych będą funkcjonować na dotychczasowych zasadach. Utrzymany zostanie swobodny przepływ kapitału. Dolar hongkoński pozostanie w obiegu i będzie swobodnie wymienialny;

- HKSAR będzie dysponował niezależnymi finansami. Centralny rząd ChRL nie będzie nakładał podatków na HKSAR;

- HKSAR może ustanowić wzajemnie korzystne stosunki gospodarcze ze Zjednoczonym Królestwem Wielkiej Brytanii i innymi państwami, których interesy gospodarcze w Hongkongu zostaną należycie uwzględnione;

- Używając nazwy Hongkong, Chiny, HKSAR może samodzielnie utrzymywać i rozwijać stosunki gospodarcze i kulturowe oraz zawierać stosowne umowy z państwami, regionami i właściwymi organizacjami międzynarodowymi;

- Rząd HKSAR może samodzielnie wydawać dokumenty podróży dotyczące wjazdu i wyjazdu z Hongkongu; 
- Utrzymanie porządku publicznego w HKSAR będzie zadaniem rządu HKSAR;

- Wyżej wymienione podstawowe założenia polityki Chińskiej Republiki Ludowej względem Hongkongu i ich wyliczenie w załączniku I do niniejszej Wspólnej deklaracji zostaną umieszczone w ustawie zasadniczej HKSAR Chińskiej Republiki Ludowej przez Ogólnochińskie Zgromadzenie Przedstawicieli Ludowych ChRL i pozostaną niezmienne przez pięćdziesiąt lat?

\section{Okres przejściowy i przekazanie administracji ChRL}

Przez trzynaście lat po podpisaniu umowy chińsko-brytyjskiej, tj. do momentu przekazania Hongkongu Chińskiej Republice Ludowej, obowiązywał okres przejściowy. Mieszkańcy regionu od samego początku żywili jednak wiele obaw. Po pierwsze, rozmowy toczyły się między Zjednoczonym Królestwem a ChRL, a obywatele Hongkongu nie mieli swojej reprezentacji i bezpośredniego głosu, a czasami nawet dostępu do informacji o ich dalszej przyszłości. Po drugie, w okresie przejściowym doszło do krwawego stłumienia protestów studenckich, co budziło skojarzenia z wydarzeniami na placu Tian'anmen. Wydarzenia z czerwca 1989 r. jedynie wzmocniły obawy Hongkończyków co do opresyjności reżimu, którego mieli stać się podwładnymi. Okres przejściowy był również niezwykle ważny ze względu na rozwój wielu instytucji politycznych w regionie, m.in. współczesnego systemu partyjnego i społeczeństwa obywatelskiego.

Do formalnego przekazania Hongkongu Chińskiej Republice Ludowej doszło 1 lipca 1997 r. Zgodnie z ustaleniami poczynionymi podczas negocjacji brytyjsko-chińskich i przepisami ustawy zasadniczej przyjętej w kwietniu 1990 r. przez Ogólnochińskie Zgromadzenie Przedstawicieli Ludowych stał się on specjalnym regionem administracyjnym Chińskiej Republiki Ludowej.

Ustawa zasadnicza utrzymywała ogólną koncepcję umocowania Hongkongu w ramach ChRL, tworząc przy tym system polityczny z monizmem egzekutywy wykonywanej przez jej szefa i powołując legislatywę zwaną Radą Ustawodawczą. Bardzo ważne dla zrozumienia obecnej sytuacji w Hongkongu są postanowienia artykułów 45 i 68 ustawy zasadniczej, które wskazują, że będzie się dążyć do wyłonienia szefa egzekutywy i Rady Ustawodawczej HKSAR w wyborach powszechnych. Do tego czasu

7 Joint declaration of the Government of the United Kingdom of Great Britain and Northern Ireland and the Government of the People's Republic of China on the question of Hong Kong, „Constitutional and Maindland Affairs Bureau” [online, dostęp: 30 XII 2019], dostępny w internecie: <https://www.cmab.gov.hk/en/issues/joint3.htm>. 
(nieokreślonego żadną konkretną datą) wybory do obu kluczowych organów miały się odbywać według istniejących regulacji, niespełniających pięcioprzymiotnikowych zasad prawa wyborczego.

\section{Społeczeństwo wobec reżimu w latach 1997-2018}

Po powstaniu HKSAR stopniowo zaczęły się nasilać napięcia między ChRL a hongkońskim społeczeństwem. Istotną cezurą stały się masowe protesty antyrządowe z 1 lipca 2003 r., w których mogło wziąć udział nawet pół miliona mieszkańców siedmiomilionowego Hongkongu. Wywołała je krytyczna ocena działalności władz HKSAR, w tym nieumiejętność poradzenia sobie z epidemią SARS ${ }^{8}$. Skala wystąpień zaskoczyła władze centralne ChRL, które od tego czasu zauważalnie rozwijają aktywne formy zaangażowania w sytuację w Hongkongu. Oznacza to m.in. większą aktywność w lokalnej polityce za pośrednictwem instytucji pełniących funkcje agend ChRL (np. największej propekińskiej partii Democratic Alliance for the Betterment and Progress of Hong Kong), podjęcie działań na rzecz integracji regionu z macierzą poprzez duże projekty infrastrukturalne czy próby szerzenia postaw lojalności wobec ChRL.

Protesty przeciwko wyburzaniu historycznych zabudowań przystani Star Ferry i Queen's Ferry w 2006 i 2007 r. nie przyciągały już tak wiele uwagi międzynarodowej opinii publicznej, ale okazały się bardzo ważne dla budowania tożsamości lokalnej i kształtowania hongkońskich ruchów społeczno-politycznych. Można je odbierać jako przejaw pogłębiania się tożsamości lokalnej, uwzględniającej także dumę z osiągnięć Hongkongu w dobie kolonializmu.

Dla budowania zdolności organizacyjnych środowisk prohongkońskich niezwykle ważne były natomiast protesty przeciwko propozycji wprowadzania w lokalnych szkołach tzw. nauczania moralnego i patriotycznego, które postrzegano jako próbę indoktrynacji politycznej według wytycznych Komunistycznej Partii Chin. Protesty, które wybuchły w 2012 r., doprowadziły m.in. do powstania ruchu Scholarism i popularności jego lidera - Joshuy Wonga.

Rozwój doktryny lokalizmu (związany m.in. z popularnością opublikowanej w 2011 r. pracy On the Hong Kong city-state autorstwa Horacego Chin Wan-kana), doprowadził do szeregu innych działań ze strony środowisk

8 Epidemia SARS (wirusa RNA należącego do koronawirusów; nazwa skrótowca pochodzi od angielskiej nazwy ciężkiego ostrego zespołu oddechowego: severe acute respiratory syndrome) trwała na przełomie 2002 i 2003 r. Pierwsze zachorowania odnotowano w Chinach, w prowincji Guangdong, a z czasem wirus rozprzestrzenił się na inne regiony Azji i świata. Do lipca 2003 r. odnotowano prawie 8,5 tys. zachorowań na całym świecie, z czego 812 zakończyło się śmiercią (w samym Hongkongu zmarło 286 osób). 
przeciwstawiających się wpływom Pekinu na Hongkong. Jedną z płaszczyzn walki stał się sprzeciw wobec aktywności mrówek z Chin kontynentalnych, które wywoziły tam hongkońskie dobra, co miało doprowadzić m.in. do znacznego wzrostu cen w regionie. Obiektem ataków ze strony części hongkońskich środowisk natywistycznych i lokalistycznych stały się także przyjazdy turystyczne Chińczyków z kontynentu. Oskarża się ich nie tylko o spowodowanie wzrostu cen w HKSAR czy ograniczenie dostępu do niektórych usług, ale wręcz o niezachowywanie czystości i naruszanie norm społecznych (np. oddawanie moczu w miejscach publicznych, krzyki, brudzenie, przepychanie się itd.).

Kulminacyjnym momentem stała się rewolucja parasolkowa, która wybuchła w drugiej połowie 2014 r. Jej bezpośrednią przyczyną było odsunięcie w czasie i ograniczenie zakresu reform prawa wyborczego Hongkongu w wyniku decyzji Komitetu Stałego Ogólnochińskiego Zgromadzenia Przedstawicieli Ludowych. Środowiska prodemokratyczne oskarżyły władze Chin o zablokowanie wprowadzenia przewidzianych w ustawie zasadniczej HKSAR bezpośrednich i powszechnych wyborów szefa egzekutywy. Decyzja Komitetu Stałego wskazywała, że ewentualne zmiany muszą wymagać od kandydata, by „kochał kraj i Hongkong” i mógł dawać gwarancję „dhugofalowego dobrobytu i stabilności Hongkongu oraz podtrzymania suwerenności, bezpieczeństwa i rozwoju interesów kraju" ". Środowiska demokratyczne odebrały te słowa jako próbę ograniczenia spektrum kandydatów do tych, którzy zostaną uznani za patriotów przez władze centralne. Co równie ważne, w powszechnych wyborach miało startować dwóch lub trzech kandydatów wskazanych przez organ, którego skład ograniczał możliwość zgłoszenia osób o prodemokratycznej orientacji politycznej.

Rewolucja parasolkowa trwała 79 dni. Ocenia się, że było w nią zaangażowanych ok. 1,2 mln osób, a w momentach kulminacyjnych w tym samym czasie i miejscu protestowało nawet 100 tys. ludzi. Szacuje się, że w trakcie demonstracji poszkodowanych zostało 2067 osób (liczono tylko tych rannych protestujących, którzy zgłosili się po pomoc medyczną), a aresztowano $955^{10}$.

9 Decision of the Standing Committee of the National People's Congress on issues relating to the selection of the Chief Executive of the Hong Kong Special Administrative Region by universal suffrage and on the method for forming the Legislative Council of the Hong Kong Special Administrative Region in the year 2016, Standing Committee of the Twelfth National People's Congress, 31 VIII 2014, dostępna w internecie [dostęp: 14 IX 2014]: $<\mathrm{http}: / /$ www.2017.gov.hk/en/decision/index.html $>$.

10 2014-2015 report on police violence in the Umbrella Movement. A report of the state violence database project in Hong Kong, The Professional Commons and Hong Kong 
Rewolucja parasolkowa wykreowała nowych liderów środowisk prodemokratycznych, natywistycznych i lokalistycznych, m.in. Joshuę Wonga (rozpoznawalnego już wcześniej jako działacza organizacji uczniowskich), Nathana Lawa czy Alexa Chowa. Po zakończeniu protestów powstały pierwsze partie polityczne, które w sposób zawoalowany nawoływały do samostanowienia Hongkongu (np. Hong Kong National Party, Demosisto, Youngspiration, Hong Kong Indigenous). O ile wystąpienia z końca 2014 r. miały charakter pokojowy, to po rewolucji można było zauważyć radykalizację środowisk politycznych: w lutym 2016 r. w dzielnicy Mongkok doszło na przykład do zamieszek i starć między policją a protestującą młodzieżą (tzw. Fishball Revolution).

Większych i mniejszych protestów można byłoby wymienić jeszcze wiele, ale istotne jest zrozumienie przyczyn tych starć. Obok politycznych, które wielokrotnie pojawiały się w wywiadach z politykami, dziennikarzami i akademikami oraz $\mathrm{w}$ wypowiedziach udzielonych autorowi w fokusowych grupach młodzieży studenckiej, bardzo często podnoszone były przyczyny społeczno-ekonomiczne. W powszechnej opinii Hongkong jawi się miastem sukcesu, ale jest to również region, w którym notuje się jeden z najwyższych na świecie poziomów rozwarstwienia społecznego według współczynnika Ginniego ${ }^{11}$. Należy też zauważyć, że już prawie 20 proc. mieszkańców HKSAR, czyli ponad 1,3 mln osób, uznaje się za żyjących poniżej granicy ubóstwa $^{12}$. Olbrzymim problemem jest tam sytuacja mieszkaniowa, a nieruchomości należą do najdroższych na świecie ${ }^{13}$. Młodzież niepokoi się też dynamiką zmian w relacji między dochodami najlepiej i najgorzej zarabiających, która wskazuje na postępujące rozwieranie się nożyc ${ }^{14}$. W ciągu zaledwie siedmiu lat majątek 10 proc. najbogatszych Hongkończyków urósł z 69,3 do 77,5 proc. stanu posiadania ogółu mieszkańców ${ }^{15}$. W latach 2003-2008

In-Media, [b.d.m.w.], dostępny w internecie [dostęp: 17 X 2015]: <http://tbinternet.ohchr. org/Treaties/CAT/Shared\%20Documents/HKG/INT_CAT_CSS_HKG_22159_E.pdf $>$.

$11 \mathrm{X} . \mathrm{Wu}$, Income inequality and distributive justice: A comparative analysis of mainland China and Hong Kong, „The China Quarterly” 2009, No. 200.

12 Hong Kong poverty situation report 2014, Government of the Hong Kong Special Administrative Region, October 2015, dostępny w internecie [dostęp: 1 II 2016]: <http://www. povertyrelief.gov.hk/pdf/poverty_report_2014_e.pdf $>$.

$1312^{\text {th }}$ annual Demographia international housing affordability survey: 2016. Rating middle-income housing affordability, Demographia, Pefrormance Urban Planning, BellevilleChristchurch [2016], dostępny w internecie [dostęp: 1 II 2016]: <http://demographia.com/ dhi2016.pdf>.

14 J.Y. Cheng, The emergence of radical politics in Hong Kong: Causes and impact, „China Review" 2014, vol. 14, No. 1.

15 B. Sautman, H. Yan, Localists and , locusts" in Hong Kong: Creating a yellow-red peril discourse, University of Maryland, 2015 (Maryland Series in Contemporary Asian Studies, 2). 
aż 62,9 proc. zatrudnionych nie awansowało zarobkowo ${ }^{16}$, a 68 proc. Hongkończyków wyraża zaniepokojenie groźbą ubóstwa ${ }^{17}$.

Trzeba jednocześnie podkreślić, że zamrożeniu wzrostu dochodów dużej części społeczeństwa towarzyszyły rozwój gospodarczy regionu i znaczny wzrost odsetka mieszkańców legitymujących się wyższym wykształceniem. Prawdopodobnie m.in. te zjawiska przyczyniają się do niskiego wyniku w badaniach poziomu szczęśliwości Hongkończyków (np. według danych World Happiness Index, w których częściowo uwzględnia się wymienione kategorie).

Wśród przyczyn politycznych należy wskazać obawy Hongkończyków związane z postępującą polityczną sinizacją regionu. W przygotowywanym przez organizację Reporterzy bez Granic rankingu wolności prasy Hongkong spadł z 18 miejsca na świecie w roku 2002 na 73 w 2019. Zauważalne są także ograniczanie wolności akademickiej czy wzrost upolitycznienia instytucji publicznych (np. policji). Ostatnie lata przyniosły wiele wydarzeń, które bardzo silnie wzmogły obawy Hongkończyków o swobody i wolności w regionie. Do najgłośniejszych należały porwania wydawców książek piętnujących Komunistyczną Partię Chin i jej przywódców, utrudnianie rejestracji w hongkońskich wyborach kandydatów wysuwanych przez ugrupowania regionalne czy oskarżenia o upolitycznienie sądownictwa ${ }^{18}$.

Mimo że na terenie Hongkongu obserwuje się liczne osadnictwo Chińczyków z ChRL ${ }^{19}$, to w badaniach Hong Kong University Public Opinion Programme z 17-20 czerwca 2019 r. rekordowe 53 proc. respondentów deklaruje się jako Hongkończycy. Im młodsza grupa, tym częstsza identyfikacja z tożsamością lokalną i mniejsze zaufanie do zasady „Jedno państwo, dwa systemy" czy władz HKSAR ${ }^{20}$.

16 Social mobility in Hong Kong: January 2015, Legislative Council, 2015 (Research Brief, 2), dostępny w internecie [dostęp: 1 II 2016]: <http://www.legco.gov.hk/research-publications/english/1415rb02-social-mobility-in-hong-kong-20150112-e.pdf>.

17 C. Lai, M.E. DeGolyer, Asian urban-wellbeing indicators comparative report: Hong Kong, Singapore, Shanghai, Civic Exchange, June 2016.

18 Ł. Zamęcki, Sinizacja systemu politycznego Hongkongu, Wydawnictwa Uniwersytetu Warszawskiego, Warszawa 2019.

19 Umożliwia to m.in. funkcjonujące od 1997 r. prawo, które pozwala, by w ramach akcji łączenia rodzin na terenie Hongkongu osiedlało się do 150 Chińczyków dziennie.

20 Categorical ethnic identity (per poll), „HKU Public Opinion Programme” [online], 27 VI 2019 [dostęp: 30 XII 2019], dostępny w internecie: <https://www.hkupop.hku.hk/ english/popexpress/ethnic/eidentity/poll/eid_poll_chart.html>. 


\section{Mobilizacja społeczna z perspektywy popytowej i podażowej}

W Hongkongu występuje obecnie wiele przesłanek, które pozwalają spodziewać się dalszych demonstracji. Ich analiza umożliwia wyjaśnienie przyczyn akcji protestacyjnych. Bert Klandermans weryfikował empirycznie potrzebę wystąpienia dalszych obok poczucia krzywdy, deprywacji i niezadowolenia czynników katalizujących wybuch protestów społecznych. Należy do nich zaliczyć m.in. struktury mobilizacji, apel polityczny, osadzenie społeczne protestujących i ich cechy społeczno-ekonomiczne oraz występowanie tożsamości grupowej21.

Jak już zauważono wyżej, niezadowolenie społeczne w Hongkongu przejawia się na co najmniej dwóch płaszczyznach - wartości politycznych i społeczno-ekonomicznych. Według badań opinii publicznej ponad połowa mieszkańców nie ma zaufania do metod realizowania przez władze centralne ChRL zasady „Jedno państwo, dwa systemy”, opowiada się po stronie szeroko rozumianego frontu demokratycznego, żąda demokratyzacji prawa wyborczego i negatywnie ocenia władze HKSAR. Jednocześnie znaczna część obywateli ma złe zdanie o stanie i perspektywach rozwoju sytuacji społeczno-ekonomicznej regionu ${ }^{22}$.

Niezadowolenie to jest jednak polityzowane poprzez rozwijającą się od kilkunastu lat sieć organizacji prodemokratycznych, natywistycznych i lokalistycznych. Siatka struktur mobilizacji obejmuje partie polityczne, organizacje społeczne (w tym bardzo aktywne zrzeszenia lokalne), niektóre związki zawodowe, a wśród osób młodych nawet fora dyskusyjne i media społecznościowe. Powszechny ruch organizacji prodemokratycznych powstał w Hongkongu na przełomie lat osiemdziesiątych i dziewięćdziesiątych XX w., a pierwsza partia prodemokratyczna - United Democrats of Hong Kong (UDHK) - w 1991 r. Przez wiele lat najważniejszą partią prodemokratyczną była powstała na bazie tego ugrupowania Partia Demokratyczna ${ }^{23}$.

21 B. Klandermans, A theoretical framework for comparisons of social movement participation, „Sociological Forum” 1993, vol. 8, issue 3; tenże, Mobilization and participation: Social-psychological expansions of resource mobilization theory, „American Sociological Review" 1984, vol. 49, issue; tenże, The social psychology of protest, Blackwell, Oxford 1997; J. van Stekelenburg, B. Klandermans, Fitting demand and supply: How identification brings appeals and motives together, „Social Movement Studies” 2014, vol. 13, No. 2.

22 Categorical ethnic identity...

23 M. Sing, Hong Kong's tortuous democratization. A comparative analysis, Routledge, London-New York 2004, Kindle e-book, lok. 1384-1391. 
Ważnym momentem kształtowania się dynamicznych ruchów protestu było założenie w 2006 r. partii radykalnych demokratów, Civic Party i League of Social Democrats, która krytykowała ociężałość Partii Demokratycznejej ${ }^{24}$ Kolejnym instytucjonalnym przejawem radykalizowania się postaw był rozwój organizacji o charakterze lokalistycznym i natywistycznym, którego obecna faza rozpoczęła się ok. 2012 r. i przyspieszyła po rewolucji parasolkowej ${ }^{25}$.

Mimo rozproszenia organizacyjnego większość ugrupowań lokalistycznych ma wspólne podwaliny ideowe - sprzeciw wobec rozszerzających się wpływów ChRL na autonomię regionu i niechęć do niektórych rażących wzorców postępowania Chińczyków z kontynentu ${ }^{26}$. Najbardziej radykalne organizacje podnoszą również kwestię niepodległości regionu.

Czynnikiem sprzyjającym mobilizacji do protestów jest rozwijająca się tożsamość hongkońska, która coraz częściej stoi w opozycji do tożsamości chińskiej. Większość protestujących stanowią osoby młodsze i dobrze wykształcone, wyraźnie odczuwające deprywację ekonomiczną. Wszystko to sprzyja narastaniu dalszych przejawów kolektywnego sprzeciwu wobec władzy HKSAR i ChRL.

\section{Rok 2019 - zmiana taktyki}

Masowe protesty w 2019 r. wywołała przedstawiona w lutym propozycja władz HKSAR, by przyjąć ustawę umożliwiającą ekstradycję mieszkańca Hongkongu do regionów, z którymi HKSAR nie podpisał w tej sprawie umowy. Przepisy te miały być bezpośrednią reakcją na dokonanie przez mieszkańca Hongkongu zabójstwa partnerki podczas wyjazdu turystycznego na Tajwan. Chodziło więc o możliwość ekstradycji na Formozę, ale duża część Hongkończyków odebrała to jako próbę zainstalowania w porządku prawnym HKSAR furtki pozwalającej na przekazywanie mieszkańców Hongkongu do Chin kontynentalnych.

24 Ma N., Political parties and elections, [w:] Contemporary Hong Kong politics. Governance in the post-1997 era, ed. W. Lam, P.L. Lui, W.W.H. Wong, I. Holiday, Hong Kong University Press, Hong Kong 2007, Kindle e-book; tenże, Political development in Hong Kong. State, political society, and civil society, Hong Kong University Press, Hong Kong 2007, Kindle e-book.

25 Ł. Zamęcki, Rewolucja...

26 Citizenship, identity and social movements in the new Hong Kong. Localism after the umbrella movement, ed. W.-M. Lam, L. Cooper, Routledge, New York 2018. 
Protesty przeciwko tej regulacji zaczęły się już w marcu 2019 r., ale na sile przybrały dopiero trzy miesiące później. 9 czerwca zgromadziły ponad milion osób, a 19 czerwca doszło do największego w historii regionu marszu protestacyjnego z udziałem ok. 2 mln mieszkańców. Tylko nieco mniejszej skali demonstracja odbyła się 18 sierpnia ${ }^{27}$.

Od lipca protesty przyjęły nową formę: stały się bardziej brutalne, zaczęły się pojawiać w wielu miejscach Hongkongu, nie były koordynowane, szybko rozpoczynały się i kończyły, jeszcze zanim policja zdążyła zareagować. Inspiracją dla demonstrantów stały się słowa Bruce’a Lee: „Bądź jak woda" (,Be water”), rozumiane jako dostosowywanie się do sytuacji i stopnia intensywności reakcji sił porządkowych. Nowa taktyka oznacza większą reaktywność na działania służb, unikanie ostrego zwarcia, przemieszczanie się protestujących $\mathrm{w}$ inne rejony Hongkongu, pojawianie się z zaskoczenia i równie szybkie znikanie, co przypomina wojnę podjazdową.

W ostatnich miesiącach policja rzeczywiście miała wiele problemów z szybką i proporcjonalną reakcją. Służby porządkowe pojawiały się w miejscach protestów z opóźnieniem, gdy młodzież dawała się już zauważyć ze swoimi hasłami, ale ich reakcja była niewspółmierna do skali zjawiska. Istotne jest również unikanie centralizacji kierownictwa protestów. W przeciwieństwie do roku 2014 nie wykreowano tu liderów, a struktura demonstracji jest umyślnie zdecentralizowana, przez co żadnej z kierujących nimi organizacji nie można uznać za wiodącą, co utrudnia rozbicie kierownictwa ruchu przez służby. Uczestnicy protestów porozumiewają się za pośrednictwem forum LIHKG oraz szyfrowanego komunikatora Telegram, a dokumentami wymieniają się poprzez dyski Airdrop ${ }^{28}$.

Istotnym problemem jest postępująca brutalizacja działań sił porządkowych. Większość protestów ma charakter pokojowy, natomiast policja odpowiada bardzo ostro i niewspółmiernie do form manifestacji. Najgłośniejsze przykłady to kierowanie pocisków z broni gładkolufowej tak, by trafiały powyżej pasa protestujących, strzelanie niepenetrującymi pociskami śrutowymi w okolice głowy, niewłaściwe i zbyt częste stosowanie gazu pieprzowego czy bicie protestujących. Nie chodzi przy tym wyłącznie o zastosowanie nieproporcjonalnych środków, ale też o ataki w miejscach

27 Przebieg protestów odtworzony został na podstawie relacji portalu „Hong Kong Free Press".

28 M. Purbrick, A report of the 2019 Hong Kong protests, „Asian Affairs” 2019, vol. 50, issue 4, DOI: 10.1080/03068374.2019.1672397. 
uniemożliwiających odróżnienie protestujących od osób postronnych, np. na stacjach metra, a nawet w wagonach kolejki. Kilkukrotne zdarzyło się również użycie gazu w pomieszczeniach zamkniętych (np. na stacji metra Kwai Fong). Oddziały policyjne wkraczały już na tereny prywatne, odmawiały pomocy medycznej i dokonywały bezpodstawnych zatrzymań. Doszło również do użycia ostrej amunicji.

Część policjantów nie nosi wymaganych prawem plakietek z nazwiskami, co utrudnia ustalenie tożsamości funkcjonariuszy łamiących prawo. Zdarzają się też przypadki, że przenikają do tłumu w cywilnych ubraniach, co rodzi coraz częstsze pytania, czy niektóre brutalne zachowania protestujących nie są inspirowane przez służby. Jednocześnie władze stosują podwójne standardy wobec manifestantów i członków triad, którzy, wspierając środowiska propekińskie, atakują protestującą młodzież.

W ciągu kilku miesięcy policja oskarżana była m.in. o nadużycia seksualne wobec demonstrantów i maltretowanie zatrzymanych. W regionie, który przez lata znany był jako wyspa praworządności w morzu autorytaryzmów, czyny te budzą przerażenie znacznej części społeczeństwa. Jednym z pięciu żądań uczestników akcji protestacyjnych jest powołanie niezależnej komisji mającej zbadać działania policji wobec manifestantów. Pozostałe to:

- całkowite wycofanie się z prac nad prawem ekstradycyjnym (15 lipca 2019 r. szefowa egzekutywy Carrie Lam ogłosiła wstrzymanie prac nad projektem ustawy, a 23 października władze Hongkongu poinformowały o wycofaniu $\mathrm{z}$ regionalnego parlamentu projektu nowelizacji prawa ekstradycyjnego, który był bezpośrednią przyczyną trwających od czerwca masowych protestów);

- rezygnacja rządu z określenia zamieszki w stosunku do pokojowych protestów z 12 lipca 2019 r. (chodzi m.in. o klasyfikację prawną czynu);

- zwolnienie osób zatrzymanych w trakcie protestów i zaprzestanie ścigania innych ich uczestników;

- last but not least - ustąpienie Carrie Lam ze stanowiska szefa egzekutywy oraz wprowadzenie powszechnych wyborów do Rady Ustawodawczej HKSAR i na stanowisko szefa egzekutywy (obecnie wybiera go 1200-osobowy komitet składający się w zdecydowanej większości z przedstawicieli różnych środowisk bliskich interesom Pekinu, a 70-osobowa legislatura tylko w niecałych 60 proc. obsadzana jest drogą powszechnych wyborów).

Protesty z 2019 r. mogą być kolejnym etapem przemiany tożsamości Hongkończyków. Wyraźniej wyeksponowano w nich sferę symboliczną, 
wykraczającą poza dotychczasowe żółte parasolki. Pojawiły się nieoficjalny hymn i flaga protestującego Hongkongu, rozwinęła się sfera obrazów i haseł. W badaniach opinii publicznej zauważalne jest też częstsze odnoszenie się do tożsamości regionalnej niż jeszcze kilkanaście miesięcy temu ${ }^{29}$.

Jednocześnie należy podkreślić, że protestujący w 2019 r. starają się ograniczać własną retorykę i unikać skojarzeń z żądaniami niepodległości Hongkongu. Choć oczywiście przy zdecentralizowanej formie demonstracji nie da się tego wyeliminować, to protestująca młodzież ma świadomość zagrożeń płynących z dążeń do niepodległości i wysuwa tylko pięć przytoczonych żądań. Działania manifestantów muszą w końcu uwzględniać możliwą reakcję władz ChRL. W 2019 r. kilkukrotnie pojawiły się obawy o fizyczną interwencję organów siłowych podlegających władzy centralnej. KPCh ocenia protesty jednoznacznie negatywnie, czemu dała wyraz m.in. w wypowiedziach rzecznika Biura ds. Hongkongu i Makau. Przekazy publikowane w chińskich mediach jednoznacznie podkreślają brutalność działań manifestantów, a kilkukrotnie sugerowano nawet inicjowanie protestów w Hongkongu przez obce państwa ${ }^{30}$.

\section{Podsumowanie}

Wybuch protestów w 2019 r. to rezultat długotrwałych napięć, których podłożem jest nie tylko postępująca sinizacja polityczna Hongkongu, ale także społeczno-ekonomiczne wyzwania stojące przed mieszkańcami regionu. Poddanie się tendencji do polityzacji wszystkich problemów w debacie publicznej mogłoby prowadzić do wniosków o wyłącznie politycznym podłożu protestów, tj. sprzeciwie wobec rozszerzającej się w Hongkongu ingerencji władz centralnych ChRL (mimo gwarancji dla regionu wynikających z zasady „Jedno państwo, dwa systemy”). Jest to oczywiście najbardziej widoczny aspekt, jednak należy podkreślić przyczyny kontekstowe, które są mniej uwypuklone, gdyż rzadko znajdują bezpośrednie odzwierciedlenie

29 Ethnic identity - Hongkonger (per poll), „Hong Kong Public Opinion Research Institute” [online, dostęp: 31 XII 2019], dostępny w internecie: <https://www.pori.hk/pop-poll/ ethnic-identity/q001/hongkonger>.

30 Zob. m.in. 美駐港總領事暗會李柱銘陳方安生，„大公網” [online], 12 VIII 2019 [dostęp: 31 XII 2019], dostępny w internecie: <http://www.takungpao.com.hk/ news/232109/2019/0812/334586.html>; 田安澜, 谁为香港反对势力赋予动乱能量? , ,环球” [online], 29 VII 2019 [dostęp: 8 VIII 2019], dostępny w internecie: <https://opinion.huanqiu.com/article/9CaKrnKIPCn>. 
na transparentach. Chodzi mianowicie o poczucie społeczno-ekonomicznej deprywacji młodzieży hongkońskiej, które jest równie ważną przyczyną napięć i pryzmatem modyfikującym postrzeganie wpływu ChRL na Hongkong. Takie wnioski można wysnuć z wywiadów i rozmów przeprowadzonych ze studentami w ramach grup fokusowych.

Intensywność protestów z 2019 r. i zmiana ich charakteru w porównaniu z wcześniejszymi przejawami niezadowolenia społecznego pozwalają stwierdzić, że ruchy społeczne się uczą. Warunki do rozwoju kolektywnej mobilizacji istnieją: struktury, apel, niezadowolenie. Obecne protesty zmieniły jednak formułę. Po rewolucji parasolkowej z 2014 r. bardzo łatwo było wskazać liderów protestów, a tym samym rozbić struktury organizacyjne i ukarać osoby uznane za prowodyrów. Demonstracje w 2019 r. nie mają centralnego przywództwa - mamy tu do czynienia z sytuacją oddolnych mniejszych protestów zwoływanych doraźnie i nagle. Ludzi, którzy wychodzą na ulice, łączy wizja Hongkongu bez wpływów Komunistycznej Partii Chin, chęć demokratyzacji lokalnego prawa wyborczego i przywiązanie do tożsamości hongkońskiej. Niepokojący jest wzrost utylitarnego i normatywnego uzasadniania przemocy. Można się spodziewać, że wciąż będzie dochodzić do protestów, a ich radykalizm nie ulegnie osłabieniu.

\section{Bibliografia}

$12^{\text {th }}$ annual Demographia international housing affordability survey: 2016. Rating middle-income housing affordability, Demographia, Pefrormance Urban Planning, BellevilleChristchurch [2016], dostępny w internecie [dostęp: 1 II 2016]: <http://demographia.com/ dhi2016.pdf>.

2014-2015 report on police violence in the Umbrella Movement. A report of the state violence database project in Hong Kong, The Professional Commons and Hong Kong In-Media, [b.d.m.w.], dostępny w internecie [dostęp: 17 X 2015]: <http://tbinternet.ohchr. org/Treaties/CAT/Shared\%20Documents/HKG/INT_CAT_CSS_HKG_22159_E.pdf>.

Categorical ethnic identity (per poll), „HKU Public Opinion Programme” [online], 27 VI 2019 [dostęp: 30 XII 2019], dostępny w internecie: <https:/www.hkupop.hku.hk/english/popexpress/ethnic/eidentity/poll/eid_poll_chart.html $>$.

Cheng J.Y., The emergence of radical politics in Hong Kong: Causes and impact, „China Review" 2014, vol. 14, No. 1.

Citizenship, identity and social movements in the new Hong Kong. Localism after the umbrella movement, ed. W.-M. Lam, L. Cooper, Routledge, New York 2018.

Contemporary Hong Kong politics. Governance in the post-1997 era, ed. W. Lam, P.L. Lui, W.W.H. Wong, I. Holiday, Hong Kong University Press, Hong Kong 2007, Kindle e-book. Decision of the Standing Committee of the National People's Congress on issues relating to the selection of the Chief Executive of the Hong Kong Special Administrative Region 
by universal suffrage and on the method for forming the Legislative Council of the Hong Kong Special Administrative Region in the year 2016, Standing Committee of the Twelfth National People's Congress, 31 VIII 2014, dostępna w internecie [dostęp: 14 IX 2014]: $<$ http://www.2017.gov.hk/en/decision/index.html>.

Ethnic identity - Hongkonger (per poll), „Hong Kong Public Opinion Research Institute” [online, dostęp: 31 XII 2019], dostępny w internecie: <https://www.pori.hk/pop-poll/ ethnic-identity/q001/hongkonger>.

Ghai Y., Hong Kong's new constitutional order. The resumption of Chinese sovereignty and the basic law, Hong Kong University Press, Hong Kong 1999, Kindle e-book.

Hong Kong poverty situation report 2014, Government of the Hong Kong Special Administrative Region, October 2015, dostępny w internecie [dostęp: 1 II 2016]: <http://www.povertyrelief.gov.hk/pdf/poverty_report_2014_e.pdf>.

Hongkong, „Google Trends” [online, dostęp: 3 I 2020], dostępny w internecie: $<$ https://trends. google.pl/trends/explore?date=2017-01-01\%202020-03-01\&geo=PL\&q=Hongkong $>$.

Joint declaration of the Government of the United Kingdom of Great Britain and Northern Ireland and the Government of the People's Republic of China on the question of Hong Kong, „Constitutional and Maindland Affairs Bureau” [online, dostęp: 30 XII 2019], dostępny w internecie: $<$ https://www.cmab.gov.hk/en/issues/joint3.htm>.

Klandermans B., Mobilization and participation: Social-psychological expansions of resource mobilization theory, „American Sociological Review” 1984, vol. 49.

Klandermans B., The social psychology of protest, Blackwell, Oxford 1997.

Klandermans B., A theoretical framework for comparisons of social movement participation, „Sociological Forum” 1993, vol. 8, issue 3.

Lai C., DeGolyer M.E., Asian urban-wellbeing indicators comparative report: Hong Kong, Singapore, Shanghai, Civic Exchange, June 2016.

Lee F. L.F., Tang G., Yuen S., Cheng E. W., Onsite survey findings in Hong Kong's anti-extradition bill protests. Research report, Centre for Communication and Public Opinion Survey, The Chinese University of Hong Kong, August 2019.

Ma N., Political development in Hong Kong. State, political society, and civil society, Hong Kong University Press, Hong Kong 2007, Kindle e-book.

Ma N., Political parties and elections, [w:] Contemporary Hong Kong politics. Governance in the post-1997 era, ed. W. Lam, P.L. Lui, W.W.H. Wong, I. Holiday, Hong Kong University Press, Hong Kong 2007, Kindle e-book.

Purbrick M., A report of the 2019 Hong Kong protests, „Asian Affairs” 2019, vol. 50, issue 4, DOI: 10.1080/03068374.2019.1672397.

Sautman B., Yan H., Localists and ,, locusts " in Hong Kong: Creating a yellow-red peril discourse, University of Maryland, 2015 (Maryland Series in Contemporary Asian Studies, 2).

Sing M., Hong Kong 's tortuous democratization. A comparative analysis, Routledge, LondonNew York 2004, Kindle e-book.

Social mobility in Hong Kong: January 2015, Legislative Council, 2015 (Research Brief, 2), dostępny w internecie [dostęp: 1 II 2016]: <http://www.legco.gov.hk/research-publications/english/1415rb02-social-mobility-in-hong-kong-20150112-e.pdf>.

Stekelenburg J. van, Klandermans B., Fitting demand and supply: How identification brings appeals and motives together, ,Social Movement Studies” 2014, vol. 13, No. 2.

Stekelenburg J. van, Klandermans B., The social psychology of protest, „Current Sociology” 2013, vol. 61, issue 5-6. 
$\mathrm{Wu} \mathrm{X}$., Income inequality and distributive justice: A comparative analysis of mainland China and Hong Kong, „The China Quarterly” 2009, No. 200.

Zamęcki Ł., Rewolucja parasolkowa w Hongkongu. Przyczyny, przebieg, następstwa, Wydawnictwa Uniwersytetu Warszawskiego, Warszawa 2018.

Zamęcki Ł., Sinizacja systemu politycznego Hongkongu, Wydawnictwa Uniwersytetu Warszawskiego, Warszawa 2019.

Zomeren M. van, Postmes T., Spears R., Toward an integrative social identity model of collective action: A quantitative research synthesis of three socio-psychological perspectives, „Psychological Bulletin” 2008, vol. 134, issue 4.

田安澜, 谁为香港反对势力赋予动乱能量?, „环球” [online], 29 VII 2019 [dostęp: 8 VIII 2019], dostępny w internecie: <https://opinion.huanqiu.com/article/9CaKrnKlPCn>.

美駐港總領事暗會李柱銘陳方安生, ,大公網” [online], 12 VIII 2019 [dostęp: 31 XII 2019], dostępny w internecie: <http://www.takungpao.com.hk/news/232109/2019/0812/334586. html>. 